\section{A gut feeling}

\section{By Tim Fulmer, Staff Writer}

Many treatments for metabolic disorders such as obesity and type 2 diabetes directly target the brain or liver (see Figure 1, "Controlling the liver via the gut" and Table 1, "Targeting diabetes and obesity"). ${ }^{1}$ Although neural communication was previously known to exist between the small intestine and the brain to curb food intake, ${ }^{2,3}$ and between the brain and the liver to mediate regulation of liver glucose production, ${ }^{4,5}$ a new study in Nature now closes the loop to reveal a complete "intestine-brain-liver" neural circuit.

Tony Lam and colleagues propose that disconnects in this circuit could be responsible for the aberrant glucose homeostasis that underlies insulin resistance, obesity and type 2 diabetes. Thus, the authors suggest that targeting nodes within the circuit could restore insulin sensitivity in people with obesity and type 2 diabetes without directly interfering with liver and brain physiology. ${ }^{6}$

Lam, corresponding author on the paper, is a researcher in the
Division of Cellular and Molecular Biology at the Toronto General Hospital Research Institute and an assistant professor of physiology and medicine at the University of Toronto.

The team's study in rats shows that a lipid-sensing mechanism in the upper intestine acts through the brain to downregulate liver glucose production in the presence of nutrient excess. Infusing small quantities of lipids directly into the upper portion of the small intestine significantly decreased liver glucose production compared with that in rats that received vehicle control $(p<0.001)$.

Surgically or pharmacologically blocking neurotransmission pathways between the intestine and the brain or between the brain and the liver abolishes the ability of infused lipids to alter liver glucose production. Therefore, upper intestinal lipids require a gut-brain-liver circuit to mediate their effects on the liver.

"Our research shows for the first time how lipid-sensing regions of the intestine can act remotely through the brain to influence liver glucose homeostasis," Lam told SciBX. "Thus, compounds that activate this mechanism could potentially reduce liver glucose production and normalize blood glucose levels in metabolic disorders."

The observation that lipids in the upper small intestine "can produce profound and rapid decreases in hepatic glucose output" prior to absorption into the blood "will attract a lot of interest in both the obesity and type 2 diabetes research communities," Jeffrey Johnson, principal scientist of biological sciences at Metabolex Inc., told SciBX.
Figure 1. Controlling the liver via the gut. The variety of tissues implicated in metabolic disorders has generated a broad range of therapeutic strategies that generally can be divided into those that target the CNS and those that target peripheral organs such as the liver and pancreas (see Table 1, "Targeting diabetes and obesity"). But a study in Nature ${ }^{6}$ suggests that restoration of plasma glucose levels could begin in cells that line the lumen of the small intestine. There, lipids derived from ingested nutrients are metabolized to fatty acids that trigger an intestine-brain-liver neural circuit, which ultimately reduces liver glucose output (blue pathway). A therapeutic targeting the lipid-sensing cells thus could help treat diabetes and obesity prior to entering systemic circulation.

Another metabolic pathway originating from the intestines implicates the release of incretins into the bloodstream. Companies already have therapeutics that target this process. For example, Byetta exenatide, a glucagon-like peptide-1 (GLP-1) receptor agonist marketed by Amylin Pharmaceuticals Inc. (NASDAQ:AMLN) and Eli Lilly and Co. (NYSE:LLY), mimics the action of incretin GLP-1 by increasing pancreatic secretion of insulin - which subsequently reduces liver glucose output and restores healthy plasma glucose levels.

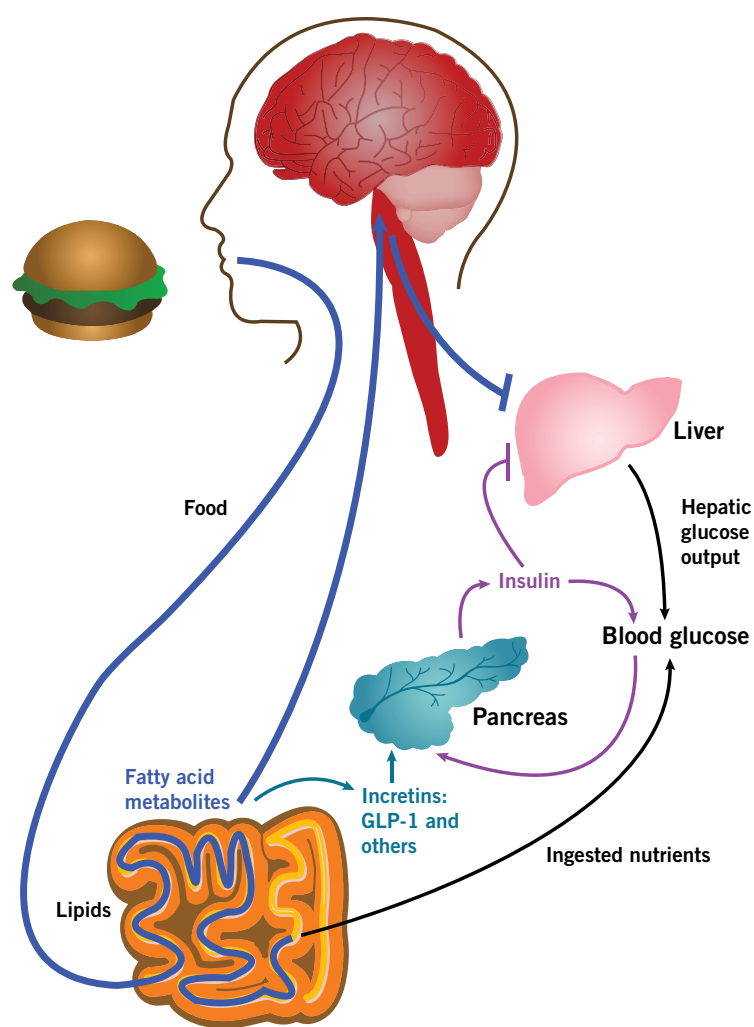


Metabolex’s MBX-102, a partial peroxisome proliferation-activated receptor- $\gamma$ (PPAR- $\gamma$ ) agonist, is in Phase II/III testing to treat type 2 diabetes.

Although giving small quantities of lipids may not be a practical approach in humans because this mechanism may be impaired in patients who are obese and/or diabetic, Johnson noted that it would be worth finding other ways to activate such lipid-sensing cells in the small intestine "in order to selectively suppress the unregulated hepatic glucose output that characterizes type 2 diabetes."

Cell-surface receptors and ion channels on the lipid-sensing cells would be obvious initial targets for small molecule modulation of the gutbrain-liver pathway, he said. "Lipid metabolism pathways within those cell types, or in the intestinal mucosa itself, could also be targeted."

Table 1. Targeting diabetes and obesity. A number of diabetes and obesity compounds in late-stage development and on the market target various pathways in different organs. Some of the most advanced programs against a given target are listed below. Compounds may affect additional tissue types than those noted.

\begin{tabular}{|c|c|c|c|c|}
\hline Company & Product & Product description & Indication & Status \\
\hline \multicolumn{5}{|c|}{ Adipose tissue, muscle \& liver } \\
\hline $\begin{array}{l}\text { GlaxoSmithKline plc (LSE:GSK; } \\
\text { NYSE:GSK) }\end{array}$ & Avandia rosiglitazone & $\begin{array}{l}\text { Peroxisome proliferation-activated receptor- } \gamma \\
(\text { PPAR- } \gamma \text { ) agonist }\end{array}$ & Diabetes & Marketed \\
\hline $\begin{array}{l}\text { Takeda Pharmaceutical Co. Ltd. } \\
\text { (Tokyo:4502)/Eli Lilly and Co. } \\
\text { (NYSE:LLY) }\end{array}$ & Actos pioglitazone & PPAR- $\gamma$ agonist & Diabetes & Marketed \\
\hline $\begin{array}{l}\text { Novo Nordisk A/S (CSE:NVO; } \\
\text { NYSE:NVO) }\end{array}$ & Levemir & Insulin receptor agonist & Diabetes & Marketed \\
\hline Novo Nordisk & Novolog & Insulin receptor agonist & Diabetes & Marketed \\
\hline \multicolumn{5}{|c|}{ Brain/CNS } \\
\hline $\begin{array}{l}\text { sanofi-aventis Group (Euronext:SAN; } \\
\text { NYSE:SNY) }\end{array}$ & $\begin{array}{l}\text { Acomplia/Zimulti } \\
\text { rimonabant }\end{array}$ & Cannabinoid $\mathrm{CB} 1$ receptor antagonist & Obesity & Marketed \\
\hline Abbott Laboratories (NYSE:ABT) & Meridia sibutramine & $\begin{array}{l}\text { Serotonin, norepinephrine and dopamine } \\
\text { reuptake inhibitor }\end{array}$ & Obesity & Marketed \\
\hline $\begin{array}{l}\text { Amylin Pharmaceuticals Inc. } \\
\text { (NASDAQ:AMLN) }\end{array}$ & Symlin pramlintide & Amylin receptor agonist & $\begin{array}{l}\text { Diabetes; } \\
\text { obesity }\end{array}$ & $\begin{array}{l}\text { Marketed } \\
\text { (diabetes); Phase II } \\
\text { (obesity) }\end{array}$ \\
\hline VeroScience LLC/S2 Therapeutics Inc. & $\begin{array}{l}\text { Cycloset } \\
\text { bromocriptine }\end{array}$ & Dopamine D2 receptor agonist & Diabetes & Phase III complete \\
\hline $\begin{array}{l}\text { Orexigen Therapeutics Inc. } \\
\text { (NASDAQ:OREX) }\end{array}$ & $\begin{array}{l}\text { Contrave naltrexone/ } \\
\text { buproprion }\end{array}$ & $\begin{array}{l}\text { Opioid receptor antagonist and } \\
\text { norepinephrine and dopamine reuptake } \\
\text { inhibitor }\end{array}$ & Obesity & Phase III \\
\hline Merck \& Co. Inc. (NYSE:MRK) & Taranabant & Cannabinoid CB1 receptor agonist & Obesity & Phase III \\
\hline 7TM Pharma A/S & Obinepitide & Neuropeptide Y (NPY) receptor agonist & Obesity & Phase II \\
\hline Nastech Pharmaceutical Co. Inc. & PYY-3-36 & NPY receptor agonist & Obesity & Phase II \\
\hline
\end{tabular}

(NASDAQ:NSTK)

\begin{tabular}{|c|c|c|c|c|}
\hline \multicolumn{5}{|c|}{ Circulation/Vasculature } \\
\hline Merck & Januvia sitagliptin & Dipeptidyl peptidase-4 (DPP-4) inhibitor & Diabetes & Marketed \\
\hline Novartis AG (SWX:NOVN; NYSE:NVS) & Galvus vildagliptin & DPP-4 inhibitor & Diabetes & Marketed \\
\hline \multicolumn{5}{|c|}{ Intestines } \\
\hline Roche (SWX:ROG) & Alli/Xenical orlistat & Pancreatic lipase inhibitor & Obesity & Marketed \\
\hline \multicolumn{5}{|c|}{ Kidney } \\
\hline $\begin{array}{l}\text { AstraZeneca plc (LSE:AZN; NYSE:AZN)/ } \\
\text { Bristol-Myers Squibb Co. (NYSE:BMY) }\end{array}$ & Dapagliflozin & $\begin{array}{l}\text { Sodium-glucose cotransporter } 2 \text { (SGLT2) } \\
\text { inhibitor }\end{array}$ & Diabetes & Phase III \\
\hline \multicolumn{5}{|c|}{ Liver } \\
\hline $\begin{array}{l}\text { Metabasis Therapeutics Inc. (NASDAQ: } \\
\text { MBRX) }\end{array}$ & MB07803 & Fructose 1,6-bisphosphatase inhibitor & Diabetes & Phase II \\
\hline \multicolumn{5}{|c|}{ Pancreas } \\
\hline Amylin/Eli Lilly & Byetta exenatide & $\begin{array}{l}\text { Glucagon-like peptide-1 (GLP-1) receptor } \\
\text { agonist }\end{array}$ & Diabetes & Marketed \\
\hline Novartis & Starlix nateglinide & $\begin{array}{l}\text { ATP-dependent potassium channel (KATP) } \\
\text { blocker }\end{array}$ & Diabetes & Marketed \\
\hline Novo Nordisk & Prandin repaglinide & KATP blocker & Diabetes & Marketed \\
\hline sanofi-aventis & Amaryl glimepiride & KATP blocker & Diabetes & Marketed \\
\hline
\end{tabular}


Identification of the intestinal hormones that mediate signaling of the sensor cells to the brain could also result in new targets for therapeutic intervention, said Nancy Thornberry, VP and research head of the diabetes division of Merck \& Co. Inc.

It is not yet known which hormones fulfill that function, and Lam agreed that "investigating the potential role of gut hormones in signal transmission between the intestine and nervous system is an important next step."

He noted the gastrointestinal peptide cholecystokinin (CKK) is one example of such a hormone. Upper intestinal lipid infusions were previously shown by another lab to induce local release of CKK. ${ }^{7}$

More broadly, the Nature paper points out "the importance of investigating the role of nonendocrine pathways in metabolic control and dysfunction," said Silvana Obici, associate professor of psychiatry and endocrinology in the Obesity Research Center at the University of Cincinnati.

"Lam's research suggests that upon sensing nutrients like lipids, some intestinal cells may release factors that directly stimulate local nerve endings rather than enter into systemic circulation in an endocrine fashion," she told SciBX. "This finding could open up a broad new area of metabolic research into molecules that transmit gut signals directly to the brain via the vagus cranial nerve."

Although further elucidation of the gut-brain-liver axis may turn up a wealth of potential targets, the Nature paper also revealed that the upper intestinal lipid-sensing mechanism may be easily impaired by a fat-heavy diet. Those findings provide yet another link between obesity and diabetes.

In rats, three days of a high-fat diet were sufficient to abolish reduc- tions in liver glucose production caused by intestinal lipids compared with what was seen in animals fed a regular diet. This finding prompted the authors to state that "in the early onset of diet-induced insulin resistance, the intestine may have acquired defect(s) in lipid sensing, hindering glucose homeostasis regulation."

Obici agreed. "In susceptible individuals, it may be that these sensors are the first line of defense to go. As a consequence, one would predict at least partial loss of control over liver glucose production, insulin resistance and increased circulating levels of insulin and glucose-the precursors of type 2 diabetes," she said.

Indeed, said Johnson, "high-fat diets have been shown to have profoundly negative impacts on glucose metabolism, and the work described in the Nature paper could explain a component of this metabolic dysregulation."

\section{REFERENCES}

1. Cooke, D. \& Bloom, S. Nat. Rev. Drug Discov. 5, 919-931 (2006)

2. Murphy, K. \& Bloom, S. Nature 444, 854-859 (2006)

3. Cummings, D. \& Overduin, J. J. Clin. Invest. 117, 13-23 (2007)

4. Obici, S. et al. Diabetes 51, 271-275 (2002)

5. Lam, T. et al. Nat. Med. 11, 320-327 (2005)

6. Wang, P. et al. Nature; published online April 9, 2008; doi:10.1038/nature06852

Contact: Tony K.T. Lam, University of Toronto, Toronto, Ontario, Canada e-mail: tony.lam@uhnres.utoronto.ca

7. Matzinger, D. et al. Gut 46, 689-693 (2000)

\section{COMPANIES AND INSTITUTIONS MENTIONED}

Merck \& Co. Inc. (NYSE:MRK), Whitehouse Station, N.J.

Metabolex Inc., Hayward, Calif.

Toronto General Hospital Research Institute, Toronto, Ontario, Canada University of Cincinnati, Cincinnati, Ohio

University of Toronto, Toronto, Ontario, Canada 